\title{
ASUHAN GIZI PADA IBU HAMIL DENGAN HIPEREMESIS GRAVIDARUM
}

\author{
Wiwin Efrizal ${ }^{1}$ \\ ${ }^{1}$ 1Dinas Kesehatan Provinsi Kepulauan Bangka Belitung \\ Jl. Pulau Bangka Kompleks Perkantoran Pemprov Babel \\ Kelurahan Air Itam Kecamatan Bukit Intan Kota Pangkalpinang \\ Email : wiwinefrizal@gmail.com
}

\begin{tabular}{l} 
Article Info \\
\hline Article history: \\
Received January $14^{\text {th }}, 2021$ \\
Revised February $21^{\text {th }}, 2021$ \\
Accepte March $25^{\text {th }}, 2021$
\end{tabular}

Keyword:

Nausea; Nutritional Care Pregnancy; Vomiting

\section{PENDAHULUAN}

Sekitar $80 \%$ ibu hamil mempunyai pengalaman merasakan mual dan muntah selama kehamilan. Pada umumnya, gejala dimulai antara empat hingga sembilan minggu kehamilan dan cenderung berkurang pada minggu ke enam belas. Kondisi mual muntah dapat berkembang menjadi hiperemesis gravidarum yang sekitar 0,5-2\% berpotensi menimbulkan kematian.(Ebrahimi et al., 2009) Hyperemesis gravidarum dapat

\begin{abstract}
Background : Hyperemesis gravidarum is a condition of nausea and vomiting that causes weight loss in pregnant women. Hyperemesis can cause malnutrition in the mother and affect the fetus and risk causing death.
\end{abstract}

Purpose : The purpose of writing is to provide a comprehensive description of nutritional care for pregnant women with hyperemesis gravidarum using the literature review method. From the study, it is known the importance of proper nutritional care for mothers with hyperemesis gravidarum in the form of a cycle of assessment, nutritional diagnosis, intervention, monitoring and evaluation which are carried out continuously to overcome the problem of hyperemesis gravidarum in collaboration with the nutrition care team.

Conclusion : The conclusion is that nutritional care with a comprehensive understanding of the problem of hyperemesis gravidarum in the form of cross-professions collaboration will improve the nutritional status of mothers.

ABSTRAK
Latar Belakang : Hiperemesis gravidarum adalah kondisi mual
muntah yang menyebabkan terjadinya penurunan berat badan pada
ibu hamil. Hiperemesis dapat menyebabkan terjadinya kekurangan
gizi pada ibu dan berdampak kepada janin serta berisiko
menimbulkan kematian.
Tujuan : Memberikan gambaran asuhan gizi pada ibu hamil dengan
hyperemesis gravidarum secara komprehensif dengan menggunakan
metode kajian literatur. Dari kajian diketahui pentingnya asuhan gizi
yang tepat pada ibu dengan yang mengalami hyperemesis
gravidarum dalam bentuk siklus pengkajian, diagnosis gizi,
intervensi, monitoring dan evaluasi yang dilakukan secara terus
menerus dapat mengatasi masalah hyperemesis gravidarum dengan
kolaborasi bersama tim asuhan gizi.
Kesimpulan : Kesimpulan yang diperoleh adalah asuhan gizi dengan
pemahaman permasalahan hyperemesis gravidarum dengan
komprehensif yang dilakukan dalam bentuk kolaborasi lintas profesi
akan memperbaiki status gizi ibu.


menyebabkan terjadinya gangguan transport polyunsaturated fatty acids (PUFA) dan/atau metabolisme pada plasenta akibat mual muntah yang parah, sehingga risiko terganggunya status gizi ibu semakin meningkat. Suplai asam lemak tak jenuh ganda (PUFA) seperti asam docosahexaenoic (DHA) dan asam arakidonat (AA) dari ibu ke janin terjadi melalui plasenta, sehingga ketersediaannya pada janin tergantung transportasi dan metabolism plasenta.(Lindberg et al., 2020).

Emesis gravidarum yang dapat berkembang menjadi hyperemesis gravidarum menyebabkan penurunan nafsu makan pada ibu yang berdampak pada perubahan keseimbangan elektrolit tubuh seperti kalsium, kalium, dan natrium hingga terjadinya perubahan metabolism tubuh. Dampak pada janin adalah terjadinya bayi dengan berat badan lahir rendah akibat kurangnya zat gizi dan cairan yang dibutuhkan dalam tumbuh kembang janin dalam kandungan.(Astuti, 2016) Oleh karena itu, asuhan gizi yang tepat akan dapat mengurangi risiko terjadinya masalah gizi dan kesehatan pada ibu dan janinnya.

\section{DEFINISI}

Perubahan fisiologis yang terjadi selama kehamilan trimester pertama dapat menimbulkan ketidaknyaman pada ibu dalam bentuk mual yang terkadang disertai muntah dengan frekuensi kurang dari 5 kali yang dikenal dengan istilah emesis gravidarum.(Munjiah et al., 2015) Emesis gravidarum sering terjadi pada masa kehamilan trimester pertama yang umumnya dimulai antara minggu ke empat dan ketujuh kehamilan serta puncaknya di sekitar minggu ke sembilan dan berakhir pada minggu ke 20.(Rofi'ah, Widatiningsih and Sukini, 2019) Emesis gravidarum dapat menimbulkan gangguan aktivitas sehari-hari, hingga dapat membahayakan jiwa ibu dan janin. (Munjiah et al., 2015)(Rofi'ah, Widatiningsih and Sukini, 2019).

Emesis gravidarum sering terjadi pada trimester pertama dengan rasa mual (nausea) umumnya terjadi pada pagi hari, namun dapat juga timbul setiap saat dan malam hari.(Munjiah et al., 2015) Seringnya gejala timbul pada saat bangun tidur, maka gejala mual dan muntah pada emesis gravidarum dikenal dengan istilah morning sickness.(Zakiyah, Emyk Windartik, Heri Tri Wibowo, 2015).

Emesis gravidarum yang bertambah berat atau dikenal sebagai hyperemesis gravidarum dengan gejala ibu terus menerus muntah setiap kali makan dan minum, akan berakibat pada lemahnya kondisi ibu, pucat dan frekuensi buang air kecil akan menurun drastic. Kondisi ini menyebabkan cairan tubuh berkurang yang berdampak pada semakin mengentalnya darah (hemokonsentrasi), penurunan konsumsi oksigen dan zat gizi ke jaringan yang dapat menimbulkan kerusakan jaringan.(Rofi'ah, Widatiningsih and Sukini, 2019).

\section{MANIFESTASI KLINIS/ETIOLOGI}

Mual adalah rasa tidak nyaman di perut bagian atas, sedangkan muntah adalah dorongan dari dalam perut yang tidak disadari dan pengeluarannya melalui esofagus sampai ke mulut.(Qudsi and Jatmiko, 2016) Mual dan muntah selama kehamilan dapat berupa gejala ringan yang khas, sedang, dan dapat sembuh dengan sendirinya dengan atau tanpa disertai muntah, hingga dapat berupa kondisi berat dalam bentuk hyperemesis gravidarum yang menyebabkan terjadinya penurunan berat badan, gangguan elektrolit dan metabolic serta jangka panjang.(Rofi'ah, Widatiningsih and Sukini, 2019) Tanda-tanda yang dapat dilihat antara lain ibu terlihat lebih kurus, turgor kulit berkurang dan mata terlihat cekung.(Histeria Friska Armynia Subratha, 2018).

Pada hyperemesis gravidarum, ibu hamil dapat mengalami penurunan berat badan lebih dari 5\% dari berat badan sebelum hamil yang disebabkan oleh terjadinya perubahan pola makan, karena nafsu makan yang menurun akibat rasa mual yang diderita.(Histeria Friska Armynia Subratha, 2018) Penurunan berat badan juga dipengaruhi oleh factor aktivitas ibu yang berlebihan, factor hormonal, dan factor infeksi.(Histeria Friska Armynia Subratha, 2018) Ibu juga akan mengalami gangguan kehamilan seperti dehidrasi, dapat mengalami syok, menghambat tumbuh kembang janin, gangguan eletrolit, cadangan karbohidrat dalam tubuh ibu akan habis, robekan pada selaput jaringan esophagus dan lambung yang terjadi karena muntah yang terlalu sering dan memiliki risiko lebih tinggi untuk melahirkan bayi dengan berat badan lahir rendah, premature dan nilai apgar kurang dari tujuh.(Indrayani, Burhan and Widiyanti, 2018).

Mual muntah pada kehamilan disebabkan terjadinya peningkatan hormone estrogen dan Human Chorionik Gonadrotropin (HCG) dalam serum. Hormon HCG merangsang produksi estrogen dalam ovarium yang menyebabkan terjadinya peningkatan keasaman lambung yang membuat ibu hamil merasa mual.(Munjiah et 
al., 2015) Terdapat perbedaan antara microbiota pada wanita hamil dengan hyperemesis gravidarum dengan wanita hamil tanpa hyperemesis gravidarum. Pajanan infeksi Helicobacter pylori diduga dapat menyebabkan terjadinya hyperemesis gravidarum. Helicobacter pylori merupakan bakteri gram negative yang berbentuk spiral dan hidup berkoloni pada lapisan mukosa lambung yang dapat menyebabkan gangguan saluran cerna.(Pratiwi, 2018) Bakteri ini termasuk sebagai agen karsinogenik kelas I dan bermanifestasi sebagai penyakit pada gastrointestinal seperti tukak lambung, gastritis kronis dan ekstraintertinal yang berhubungan dengan kardiopulmoner, hematologi, metabolik, neurologis dan system dermatologis.(Muhammad Miftahussurur, Heasty Oktaricha, 2020).

Emesis gravidarum lebih sering terjadi pada primigravida, karena kemampuan beradaptasi dengan hormone estrogen dan koreonik gonadotropin lebih rendah bila dibandingkan dengan multigravida dan grandemultigravida.(Zakiyah, Emyk Windartik, Heri Tri Wibowo, 2015) Selain itu, emosi selama hamil dan kekhawatiran yang timbul karena mual dan muntah lebih sering dialami pada primigravida yang menunjukkan kurangnya pengetahuan, informasi dan komunikasi serta pengalaman tentang gejala emesis gravidarum dan kemampuan untuk mengatasinya.(Zakiyah, Emyk Windartik, Heri Tri Wibowo, 2015).

Emesis gravidarum dapat disebabkan oleh factor psikologis seperti pada kehamilan yang tidak diinginkan, perasaan marah, bersalah, cemas dan ketakutan yang akan menambah mual muntah.(Rofi'ah, Widatiningsih and Sukini, 2019) Faktor yang menjadi penyebab terjadinya hyperemesis gravidarum belum diketahui dengan jelas, karena hyperemesis memiliki multifactor atau merupakan hasil akhir dari berbagai kondisi terkait.(Subriani, 2018).

Factor stress merupakan salah satu penyebab yang mempengaruhi emesis gravidarum dari sisi psikologis, meskipun hubungannya belum diketahui dengan jelas.(Syamsuddin, Lestari and Fachlevy, 2018) Kondisi stres akan mempengaruhi hipotalamus dan memberikan rangsangan pada bagian tengah otak, sehingga terjadi kontraksi pada otot perut dan otot dada yang disertai dengan penurunan diafragma. Hal ini akan menyebabkan terjadinya tekanan tinggi pada perut, tekanan tinggi pada perut memaksa ibu untuk mengambil nafas dalam membuat sfingter esofagus bagian atas terbuka dan sfingter relaksasi bagian bawah inilah yang memicu mual dan muntah.(Mardiyanti and Zuwariyah, 2019).

\section{PATOFISIOLOGI}

Mual dan muntah dapat berlangsung dalam jangka waktu pendek dan panjang dan pada umumnya mual muntah yang terjadi pada jangka pendek tidak membahayakan. Mual dan muntah yang terjadi dalam jangka panjang akan menimbulkan dehidrasi, sehingga keseimbangan eletrolit di dalam tubuh terganggu dan dapat membahayakan jiwa.(Qudsi and Jatmiko, 2016).

Muntah yang terjadi diawali dengan stimulasi otot polos di medulla yang mengendalikan otot polos yang ada di dinding lambung dan otot skeletal di abdomen serta system pernapasan, dan zona pemicu kemoreseptor berada di luar sawar darah otak zoma pemicu kemoreseptor. Kemoreseptor ini bertanggung jawab juga terhadap kejadian mual dan muntah yang diakibatkan oleh pergerakan. Stimulus dalam zona pemicu kemoreseptor dihantarkan ke pusat muntah yang menyebabkan otot dalam saluran gastrointertinal dan pernapasan memulai terjadinya muntah.(Zakiyah, Emyk Windartik, Heri Tri Wibowo, 2015).

Emesis gravidarum yang jika tidak mendapatkan penanganan yang tepat akan berlanjut menjadi hyperemesis gravidarum. Pada hyperemesis gravidarum, ibu hamil akan mengalami mual dan muntah hebat lebih dari 10 kali sehari dan mengalami kekurangan cairan dan penurunan berat badan yang berdampak pada terganggunya aktivitas sehari-hari dan membahayakan janin dalam kandungan.(Munjiah et al., 2015) Mual dan muntah yang berlangsung terus menerus akan menyebabkan berkurangnya cairan tubuh, sehingga darah menjadi lebih kental (hemokonsentrasi) dan sirkulasi darah ke jaringan terhambat. Kondisi ini menimbulkan kerusakan jaringan yang dapat mengganggu kesehatan ibu dan perkembangan janinnya.(Rofi'ah, Widatiningsih and Sukini, 2019) 
Tabel 1. Klasifikasi Hiperemesis Gravidarum

\begin{tabular}{cl}
\hline $\begin{array}{c}\text { Grade/ } \\
\text { Tingkatan }\end{array}$ & \multicolumn{1}{c}{ Gejala/Tanda-tanda } \\
\hline I & $\begin{array}{l}\text { Mual muntah terus menerus yang mempengaruhi keadaan umum ibu dan ibu merasa lemah, } \\
\text { nafsu makan tidak ada, berat badan menurun dan rasa nyeri pada epigastrum. Nadi } \\
\text { meningkat } \pm 100 \text { kali per menit, tekanan darah sistolik menurun, turgor kulit berkurang, } \\
\text { lidah mengering dan mata cekung. }\end{array}$ \\
& $\begin{array}{l}\text { Mual muntah yang hebat berakibat keadaan umum penderita lebih parah, lemah dan apatis, } \\
\text { turgor kulit lebih berkurang, lidah mengering dan nampak kotor, nadi kecil dan cepat, suhu }\end{array}$ \\
II & $\begin{array}{l}\text { kadang-kadang naik dan mata sedikit ikteris, berat badan turun dan mata cekung, tensi } \\
\text { turun, hemokonsentrasi, oligouria dan konstipasi, dapat juga asetonuria dan dari napas } \\
\text { tSedang) }\end{array}$ \\
III & $\begin{array}{l}\text { Keadaan umum penderita lebih jelek, muntah berhenti, kesadaran menurun dari somnolen } \\
\text { sampai koma, nadi kecil dan cepat, dehidrasi berat, suhu meningkat dan tensi menurun. }\end{array}$ \\
\hline
\end{tabular}

Perubahan pada system endokrin yang terjadi selama kehamilan dapat menyebabkan mual dan muntah, terutama disebabkan tingginya fluktuasi kadar HCG pada periode gestasional 12 - 16 minggu pertama pada saat kadar tertinggi HCG disekresi oleh sel-sel trofoblas blastosit terjadi. HCG disekresi dari sekitar tiga minggu gestasi (yaitu satu minggu setelah fertilisasi) dan terjadinya peningkatan jumlah jaringan plasenta akan meningkatkan total waktu terjadinya rasa mual di awal kehamilan. HCG menyebabkan terjadinya penurunan Thyroid Stimulating Hormone (TSH) pada ibu hamil yang menderita hyperemesis gravidarum yang mengalami peningkatan fungsi tiroid dengan sebagian kecil mengalami tirotoksikosis gestasional dengan serum HCG melebihi 200 IU.(Rofi'ah, Widatiningsih and Sukini, 2019)

Peningkatan HCG akan menginduksi ovarium, sehingga produksi estrogen akan meningkat dan berakibat merangsang mual dan muntah.(Subriani, 2018) Selain karena peningkatan HCG, peningkatan hormone estrogen atau progesterone, relaksasi otot-otot halus, perubahan dalam metabolism karbohidrat yang berlebihan, mekanisme kongesti, inflamasi, distensi pergeseran, factor alergis disebabkan sekresi korpus luteum, antigen dari ayah, iso agglutinin, keracunan histamin dapat memicu mual dan muntah.(Yuliana, 2019)

Meskipun peningkatan kadar hormone dan pengaruh perubahan psikologis diperkirakan sebagai penyebab emesis gravidarum, namun kondisi ini direspon berbeda oleh ibu hamil dengan derajat mual dan muntah yang berbeda-beda, mulai dari tidak ada gejala mual muntah hingga mengalami mual muntah setiap saat.(Nurazizah, 2018)

Mekanisme mual dan muntah dikendalikan oleh keseimbangan hormone serotonin yang berfungsi sebagai neurotransmitter. Serotonin berfungsi untuk mencegah berlangsungnya mual muntah berlebihan untuk menjaga keseimbangan eletrolit tubuh.(Faridah, 2020) Emesis gravidarum menyebabkan penurunan nafsu makan yang berdampak pada terjadinya perubahan keseimbangan elektrolit seperti kalium, kalsium dan natrium yang mengakibatkan perubahan metabolism tubuh.(W and Pertiwi, 2012)

Ibu dengan primigravida mempunyai risiko menderita hyperemesis gravidarum daripada multigravida, karena belum mampu beradaptasi dengan hormone estrogen dan khorionik gonadotropin. Estrogen memiliki banyak efek pada saluran gastrointestinal, karena tingginya kadar estrogen berakibat pada waktu transit usus lebih lambat dan menghambat pengosongan lambung.(Nurbaity, Candra and Fitranti, 2019)

Peningkatan pada kedua hormone ini membuat kadar asam lambung meningkat sehingga menimbulkan rasa mual. Keluhan mual terjadi pada pagi hari yang pada umumnya perut dalam keadaan kosong, peningkatan asam lambung dan penurunan kadar gula darah berdampak pada timbulnya pusing, lemas dan mual. Janin yang memproduksi hormone khorionik gonadotropin akan merangsang indung telur untuk terus meningkat selama kehamilan, sehingga berpengaruh pada melambatnya gerakan dan mengendurnya otot-otot system pencernaan dengan tujuan agar gizi makanan dapat lebih banyak diserap oleh janin. Pengenduran otot polos pada area Rahim dan katup antar perut dan kerongkongan yang ikut terpengaruh akan memicu meningkatkan asam lambung.(Indrayani, 2018) 
Peningkatan produksi estrogen dapat dipengaruhi oleh peningkatan lemak tubuh. Lemak dalam makanan dapat menunda pengosongan lambung dengan menghambat pelepasan gastrin dan mempengaruhi aktivitas ritmis lambung. Selain itu, lemak juga dapat menghambat protein dalam mempertahankan aktivitas lambung secara normal.(Nurbaity, Candra and Fitranti, 2019)

Peningkatan hormon estrogen akan menghambat kinerja enzyime kynureninase yang mempengaruhi triptofan. Triptofan merupakan asam amino yang penting bagi manusia tetapi hanya tertahan sebagai asupan gizi dari proses pencernaan dengan enzim proteolitik. Pada mual muntah, triptofan berfungsi untuk melepaskan serotonin dan niasin, sehingga panca indera lebih peka dan mual muntah akan lebih mudah terjadi.(Oktavia, N. Sari., Susanti, Dewi., and Anggalia, 2018)

Muntah terjadi dalam 2 tahapan, yaitu tahap awal dan tahap pengeluaran. Pada tahap awal terjadi kontraksi pada perut yang disebabkan otot perut dan otot-otot pernapasan bersama-sama mengalami pemutaran dan penderita hanya merasakan mual dan tidak sampai pada fase pengeluaran. Pada fase pengeluaran terjadi pergeseran otot diafragma dan otot perut yang menyebabkan kontraksi yang lebih kuat dan umumnya berlangsung dalam waktu yang cukup lama. Namun, tekanan akibat kontraksi dapat dilepaskan melalui sfingter esofagus bagian atas yang mengalami relaksasi, sehingga isi lambung dapat dikeluarkan.(Qudsi and Jatmiko, 2016) Ibu hamil yang mengalami emesis gravidarum memerlukan adanya dukungan social dari lingkungan sekitarnya, baik dari keluarga, teman dan tenaga kesehatan.

Asupan karbohidrat, protein dan lemak jenuh, asupan asam lemak omega-3, asam lemak omega-6 dan vitamin B6 dapat mempengaruhi hyperemesis gravidarum. Asupan karbohidrat, protein dan lemak akan mempengaruhi irama lambung normal, sehingga menimbulkan distrimia lambung yang bermanisfestasi dalam bentuk mual muntah. Konsumsi dalam jumlah banyak karbohidrat mempunyai hubungan dengan kejadian mual muntah pada ibu hamil.(Nurbaity, Candra and Fitranti, 2019)

Peningkatan kebutuhan protein yang tinggi selama kehamilan sebagai efek dalam pembentukan sel-sel baru dapat menimbulkan defisinesi protein bila kebutuhan tersebut tidak terpenuhi. Defisiensi protein dalam waktu cepat akan menimbulkan distrimia lambung dan bermanifestasi dalam bentuk mual. Konsumsi protein dalam jumlah cukup dapat merangsang sekresi gastrin yang berperan dalam mempertahankan irama lambung.(Nurbaity, Candra and Fitranti, 2019)

Komponen bioaktif utama asam lemak tak jenuh omega-3, yaitu Eicosapentaenoic acid (EPA) dan Docosahexaenoicacid (DHA). Kekurangan Docosahexaenoicacid (DHA) berdampak pada disfungsi stabilitas membrane neuron dan transmisi serotonin, norepinefrin, dan dopamine yang berhubungan dengan penyebab mood dan disfungsi. Serotonin berperan dalam mencegah terjadinya mual dan muntah. EPA berperan penting dalam menyeimbangkan fungsi kekebalan dan Kesehatan fisik dengan menekan efek proinflamasi asam arakhidonat (asam lemak tak jenuh omega-6), sehingga mengurangi sintesis prostaglandin E2 yang berkaitan dengan depresi. Asam arakhidonat (AA) merupakan substrat utama untuk prostaglandin E2, sehingga diet tinggi AA dapat meningkatkan glukokortikoid dan prostaglandin E2 serta kecemasan. Prostaglandin E2 dianggap turut berperan dalam pathogenesis mual dan muntah pada ibu hamil, karena efeknya pada kontraksi otot polos longitudinal dan relaksasi otot polos melingkar.(Nurbaity, Candra and Fitranti, 2019)

Muntah yang dikeluarkan dapat dibedakan atas 3 warna, yaitu (1) muntah berwarna merah terang berasal dari perdarahan di kerongkongan, (2) muntah warna merah gelap berasal dari perdarahan di perut, seperti ulkus perforasi, (3) muntah berwarna kuning berasal dari cairan empedu yang disebabkan oleh terbukanya katup pilorus, sehingga cairan empedu mengalir dari duodenum menuju ke dalam perut.(Qudsi and Jatmiko, 2016) Hyperemesis gravidaraum dapat membahayakan jiwa ibu dan janin, karena dapat menyebabkan terjadinya abortus, berat badan lahir rendah dan terhambatnya pertumbuhan janin (intrauterine growth retardation (IUGR).(Faridah, 2020)

\section{FAKTOR RISIKO}

Factor yang mempengaruhi emesis gravidarum terdiri dari factor fisiologis dan factor predisposisi.(Zakiyah, Emyk Windartik, Heri Tri Wibowo, 2015) factor risiko yang berhubungan dengan hyperemesis gravidarum antara lain kejadian hyperemesis gravidarum pada kehamilan sebelumnya, berat badan berlebih, kehamilan multiple, penyakit trofoblastik, nuliparitas dan merokok.(Gunawan, Manengkei and Ocviyanti, 2011) 
Hiperemesis gravidarum dapat dipengaruhi oleh beberapa factor, yaitu factor hormonal, factor psikologis, factor paritas, factor gizi, dan factor alergi.(Maulina, Megamaulia and Widia, 2016)

Faktor disposisi yang mengaruhi emesis gravidarum adalah tingkat pengetahuan, tingkat pendidikan, umur, primigravida, molahidatidosa, dan kehamilan ganda akibat peningkatan kadar HCG.(Histeria Friska Armynia Subratha, 2018) (Yuliana, 2019)

Kehamilan merupakan salah satu factor patogenesa perusakan akut dari gastritis kronis, disebabkan pergerakan otot polos traktus gastrointestinal ditekan oleh progesterone, sedangkan sekresi asam lambung mengalami peningkatan selama hamil. Pada awal kehamilan, terjadi peningkatan retensi cairan dalam tubuh dan perubahan volume cairan intraselular-ekstraselular yang disebabkan oleh peningkatan hormone steroid dan berakibat pada perubahan $\mathrm{pH}$. Perubahan $\mathrm{pH}$ yang terjadi pada tractus gastrointestinal dapat menyebabkan reaktivitasi infeksi laten dari Helicobacter pylori.(Syamsuddin, Lestari and Fachlevy, 2018)

\section{PENCEGAHAN}

Upaya pencegahan yang dapat dilakukan antara lain adalah :

- Meningkatkan pengetahuan ibu terkait kehamilan dan emesis gravidarum. Komunikasi, informasi dan edukasi (KIE) dalam bentuk penyuluhan dan konseling tentang kehamilan dan emesis gravidarum perlu dilakukan untuk mempersiapkan ibu dalam menerima kehamilannya dan mengatasi gejala emesis gravidarum bila terjadi.

- Meningkatkan dukungan keluarga, terutama suami dalam mendukung istrinya sebelum dan selama kehamilan. Dukungan emosional suami kepada istrinya dapat menimbulkan ketenangan batin dan perasaan senang dalam diri istri, sehingga lebih mudah dalam menyesuaikan pada kondisi kehamilannya. Lingkungan keluarga dan sekitar yang nyaman akan mengurangi tingkat stress ibu.(Merlin Karinda, 2018)(Syamsuddin, Lestari and Fachlevy, 2018)

- Meningkatkan pengetahuan ibu tentang cara mengurangi dan mengatasi mual muntah bila terjadi selama kehamilan

- Melakukan konseling gizi dan kesehatan

- Memantau status gizi dan Kesehatan sebelum dan selama hamil. Ibu hamil sebaiknya tidak terlalu cepat bangun dari tempat tidur, sehingga adaptasi aliran darah menuju susunan saraf pusat dapat tercapai dengan baik. Selain itu, ibu hamil juga diharapkan selalu menjaga kebersihan mulut dan gigi.(Histeria Friska Armynia Subratha, 2018) (Nurazizah, 2018)(W and Pertiwi, 2012)

\section{PENGOBATAN}

Penanganan mual dan muntah pada ibu hamil disesuaikan dengan derajat keparahan yang dirasakan. Pengobatan dapat dilakukan dengan menggunakan terapi farmakologis maupun non farmakologis. Terapi farmakologis dilakukan dengan pemberian piridoksin (vitamin B6) dalam dosis $10 \mathrm{mg}$ ditambah 12,5 mg doxylamine per oral setiap 8 jam, antiemetic, antihistamin, antikolinergik dan kortikosteroid, sedangkan terapi non farmakologis dilakukan dengan pemberian konseling gizi dan kesehatan, pengaturan diet, dukungan emosional, akupunktur, perubahan pola hidup, istirahat, tidur dan pengobatan herbal/alamiah dalam bentuk aromaterapi menggunakan jahe, spearmint, lemon dan peppermint.(Rofi'ah, Widatiningsih and Sukini, 2019) (Mardiyanti and Zuwariyah, 2019) (Gunawan, Manengkei and Ocviyanti, 2011).

Beberapa herbal aromaterapi yang dapat dimanfaatkan antara lain :

- Jahe mengandung minyak atsiri Zingiberena (zingirona), zingiberol, bisabilena, kurkumen, gingerol, flandrena, vitamin A dan resin pahit yang dapat memberikan rasa nyaman di perut, sehingga mual dan muntah dapat diatasi.(Rofi'ah, Widatiningsih and Sukini, 2019)

- Lavender yang memiliki zat aktif berupa linalool dan linalyl acetate yang dapat berefek sebagai analgesic dapat dimanfaatkan sebagai aromaterapi.(Rofi'ah, Widatiningsih and Sukini, 2019)

- Lemon menghasilkan minyak esensial dari ekstrak kulit jeruk (Citrus Lemon) dan sering digunakan untuk kehamilan dan melahirkan. Lemon mengandung Limonene yang dapat menghambat kerja prostaglandin, sehingga mengurangi rasa nyeri serta berfungsi mengontrol sikooksigenase I dan II, mencegah aktivitas prostaglandin dan mengurangi rasa sakit, termasuk mual dan muntah. Kandungan lilalil asetat pada lemon berfungsi untuk menormalkan keadaan emosi serta memiliki khasiat sebagai penenang dan tonikum, khususnya pada system syaraf.(Rofi'ah, Widatiningsih and Sukini, 2019) 
Pemberian infus D5\% drip ondancentron $4 \mathrm{mg}$ setiap 8 jam untuk mengurangi mual muntah, injeksi ranitidine dengan dosis $50 \mathrm{mg}$ per 8 jam atau pemberian antasida syrup dengan dosis $125 \mathrm{ml}$ dalam 3 kali 1 sdm per 5 jam dapat dipertimbangkan untuk mengurangi asama lambung agar tidak terjadi peningkatan. Pemberian farmakoterapi harus dilakukan sesuai dengan nasehat dokter.(Wulandari Agustina, 2018).

\section{ASUHAN GIZI \\ Pengkajian Gizi}

Anamnesa

Pada kegiatan anamnesa dilakukan kegiatan untuk mendapatkan informasi terkait identitas umum penderita meliputi nama, umur, riwayat kehamilan dan kesehatan serta Riwayat emesis gravidarum pada kehamilan sebelumnya dan saat sekarang. Keluhan yang dirasakan oleh ibu terkait frekuensi mual muntah yang terjadi, kemungkinan penyebab, riwayat penyakit berulang, rasa sakit yang dirasakan. Selain itu dilakukan pendalaman terkait factor-faktor risiko yang meliputi umur, usia melahirkan anak pertama, jumlah anak, riwayat menyusui, riwayat menstruasi, riwayat penggunaan obat hormonal, dan riwayat keluarga yang berhubungan dengan hyperemesis gravidarum, pekerjaan, tingkat pendidikan, paritas, umur kehamilan serta factor lain yang mungkin menyebabkan seperti kurangnya dukungan keluarga.

Riwayat terkait asupan makanan dan gizi yang meliputi pola konsumsi ibu, pemberian makanan dan gizi, bahan makanan dan/atau minuman yang dikonsumsi, penggunaan obat/herbal suplemen, pengetahuan/ kepercayaan, ketersediaan makanan dan persediaan, serta aktivitas fisik.

Riwayat penderita yang meliputi riwayat medis/kesehatan/keluarga, perawatan dan penggunaan pengobatan komplementer /alternatif, riwayat social, riwayat ibu dan kehamilan, riwayat kehamilan, keaksaraan, status social ekonomi, situasi tempat tinggal/perumahan, dukungan social, lokasi geografis, dan akses terhadap pelayanan kesehatan dan gizi serta perilaku hidup bersih dan sehat (PHBS).

\section{Pemeriksaan fisik}

Pemeriksaan fisik meliputi pemeriksaan tanda-tanda vital seperti nadi, pernapasan, dan tekanan darah. Pemeriksaan fisik/klinis terkait gizi seperti massa otot dan lemak, fungsi menelan, nafsu makan, dan masalah saat makan dan minum yang terjadi (kemampuan mengunyah dan menelan). Pengukuran antropometri dilakukan untuk mengetahui kebutuhan gizi dan kondisi status gizi ibu yang meliputi tinggi badan, berat badan, Indeks Massa Tubuh (IMT), dan riwayat berat badan. Pemeriksaan dengan cara inspeksi dalam bentuk pengamatan dengan mata terhadap penampakan kondisi umum ibu. Periksa perubahan kulit yang terjadi dilakukan untuk mengetahui kemungkinan terjadinya kekurangan cairan pada ibu.

\section{Pemeriksaan penunjang}

Pemeriksaan penunjang yang dapat dilakukan adalah pemeriksaan kadar haemoglobin $(\mathrm{Hb})$ dengan rentang normal 10-15 g/dl, eritrosit dengan rentang normal 4,0-5,5 sel/mm3, hematokrit dengan rentang normal 30$46 \%$. Selain itu, dapat juga dilakukan pemeriksaan USG untuk memastikan kondisi janin. Pemeriksaan laboratorium lainnya seperti glukosa darah, hemoglobin, kolesterol dan profil lipid lainnya, asam urat dan elektrolit.(Wulandari Agustina, 2018)

\section{Diagnosa Gizi}

Diagnosis gizi digunakan untuk mengidentifikasi dan menggambarkan masalah gizi spesifik yang dapat diatasi atau diperbaiki melalui intervensi gizi. Diagnosis gizi meliputi definisi masalah, kemungkinan etiologi/penyebab, dan tanda atau gejala umum yang telah diidentifikasi dalam tahap pengkajian gizi. Ada tiga kategori diagnosis gizi yang meliputi domain asupan dengan cara membandingkan asupan makan atau gizi dengan kebutuhan actual atau perkiraan, domain klinis yang menghubungkan masalah gizi dengan kondisi medis atau fisik, dan domain perilaku dan lingkungan yang terkait sikap, kepercayaan, lingkungan fisik, akses terhadap makanan dan keamanan pangan.(Masyarakat, 2018).

Pada kasus hiperemesis, domain asupan menjadi lebih dominan, sehingga diagnosis gizi yang dapat ditetapkan adalah "Kurangnya berat badan ibu hamil yang berkaitan dengan kondisi hyperemesis gravidarum ditandai dengan IMT < 18,5 kg/m3, mual, muntah dan asupan energi <70\% AKG”.(Masyarakat, 2018). 


\section{Intervensi Gizi}

Intevensi gizi bertujuan untuk memperbaiki dan meningkatkan kondisi gizi berdasarkan rencana dan penerapan intervensi gizi yang tepat sesuai dengan kebutuhan. Intervensi gizi dikelompokkan dalam empat kategori, yaitu pemberian makan, edukasi gizi, konseling gizi, koordinasi asuhan gizi.(Masyarakat, 2018)

\section{Pemberian makan}

Tujuan diet hyperemesis gravidarum adalah mengganti persediaan glikogen tubuh dan mengontrol asidosis serta secara berangsur memberikan makanan berenergi dan zat gizi yang cukup. Syarat yang harus dipenuhi pada diet hyperemesis gravidarum adalah kebutuhan karbohidrat tinggi (75-80\% dari kebutuhan energi total), lemak rendah ( $\leq 10 \%$ dari kebutuhan energi total), protein sedang (10-15\% dari kebutuhan energi total), diberikan dalam bentuk kering dan pemberian cairan disesuaikan dengan kondisi penderita dalam jumlah 7 10 gelas per hari. Makanan mudah cerna, tidak merangsang saluran cerna dan diberikan sering dalam porsi kecil dan bila makan pagi dan siang sulit diterima, dapat dilakukan optimalisasi pada makan malam dan selingan malam. Secara berangsur, makanan ditingkatkan dalam porsi dan nilai gizi sesuai dengan keadan dan kebutuhan gizi penderita.

Diet hyperemesis gravidarum dapat dikelompokkan dalam tiga macam, yaitu Diet Hiperemesis I, II, dan III. Diet Hiperemesis I diberikan kepada kasus hyperemesis berat dalam bentuk roti kering, singkong bakar atau rebus, ubi bakar atau rebus, dan buah-buahan. Cairan sebaiknya tidak diberikan bersamaan dengan makanan, namun 1-2 jam sesudahnya. Makanan ini mengandung kurang hampir semua zat gizi, kecuali vitamin C, sehingga hanya diberikan dalam beberapa hari.

Diet hiperemesis II diberikan bila rasa mual dan muntah sudah berkurang. Pada kondisi ini, pemberian makanan dari bahan makanan yang bernilai gizi tinggi mulai dapat diangsur dan minuman sebaiknya tidak diberikan bersamaan dengan makanan. Pada diet hiperemesis III diberikan pada kasus hyperemesis ringan dengan modifikasi dilakukan sesuai kesanggupan penderita. Minuman dapat diberikan bersamaan dengan makanan dan makanan pada diet ini telah cukup energi dan semua zat gizi.(Instalasi Gizi Perjan RS Dr. Ciptom Mangunkusumo, 2005)

Pada perhitungan kebutuhan gizi ibu hamil, perlu dilakukan pendataan terkait identitas ibu, riwayat kesehatan termasuk riwayat kehamilan sebelumnya bila ada, riwayat gizi dan data antropometri serta tanda-tanda dan atau gejala-gejala klinis yang ada, termasuk data mual muntah yang diperoleh melalui wawancara.

Kebutuhan gizi ibu hamil dapat dihitung berdasarkan Angka Kecukupan Gizi yang Dianjurkan (AKG) tahun 2019 pada wanita dewasa yang dikelompokkan menurut umur berkisar antara 2100-2250 kkal ditambah selama kehamilan sebesar $180 \mathrm{kkal}$ pada trimester pertama, dan $300 \mathrm{kkal}$ pada trimester dan kedua. Kebutuhan dibutuhkan sebesar 60 gram dengan penambahan 1 gram pada trimester pertama, sebanyak 10 gram pada trimester kedua serta 30 gram pada semester ketiga. Kebutuhan karbohidrat berkisar 300-260 gram dengan penambahan 25 gram pada trimester pertama, dan 40 gram pada trimester kedua dan ketiga.(Kementerian Kesehatan Republik Indonesia, 2019)

Kebutuhan gizi ibu hamil didasarkan pada pertimbangan adanya penyesuaian faal selama kehamilan dalam bentuk peningkatan basal metabolisme. Metabolisme basal pada empat bulan pertama akan mengalami peningkatan yang pada 20 minggu terakhir menurun 20-25\%, karena perubahan fungsi organ pencernaan yang disebabkan perubahan hormonal (peningkatan HCG, estrogen, progesterone) yang menimbulkan efek mual muntah, motilitas lambung, motilitas usus, peningkatan fungsi ginjal, peningkatan volume dan plasma darah hingga $50 \%$ dan jumlah erytrosit $20-30 \%$, sehingga terjadi penurunan hemodilusi dan konsentrasi hemoglobin.(Darniati, 2017)

Kondisi Hiperemesis gravidarum yang ditandai dengan mual dan muntah yang berlebihan akan menyebabkan cadangan karbohidrat digunakan untuk memenuhi kebutuhan energi, sehingga metabolism tubuh menggunakan lemak dan protein sebagai sumber energi. Pembakaran lemak yang kurang sempurna akan membentuk badan keton di dalam darah yang dapat memperberat kondisi klinis.(Maulina, Megamaulia and Widia, 2016)

Makanan yang memicu terjadinya mual muntah seperti makanan berlemak dan berbumbu tajam, sebaiknya dihindari. Konsumsi ibu disarankan dalam porsi kecil tapi sering dengan mengkonsumsi makanan sedikit demi sedikit namun sering guna menghindari pengosongan lambung yang terlalu lama dan membantu proses 
metabolism karbohidrat yang baik.(Rofi'ah, Widatiningsih and Sukini, 2019) Kondisi lambung yang kosong akan menyebabkan asam lambung mengiritasi dinding lambung, sehingga memicu terjadinya mual. Rasa mual akan meningkat bila pola makan yang salah seperti sering terlambat makan, mengkonsumsi makanan yang terlalu pedas dan asam serta minuman bersoda.(Rinata and Ardillah, 2015)

Konsumsi protein sangat dibutuhkan untuk menunjang perkembangan jaringan janin. Defisiensi protein selama kehamilan dapat menyebabkan gangguan pertumbuhan intrauterine dan berat badan lahir rendah, yang berisiko meningkatkan morbiditas dan mortalitas bayi serta berdampak pada penyakit kronis pada kehidupan selanjutnya. Konsumsi protein hewani pada umumnya dihindari oleh ibu penderita emesis atau hyperemesis gravidarum dengan alasan bau amis produk hewani yang dapat memicu mual. Namun, dalam kondisi tersebut dapat digantikan dengan memilih sumber protein nabati seperti kedelai. Meskipun demikian, tidak sepenuhnya sumber protein nabati dapat menggantikan sumber protein hewani, karena sumber protein hewani mengandung 9 asam amino, sedangkan protein nabati mengandung asam amino essensial tertentu yang lebih rendah seperti lisin, metionin, sistein, dan threonine.(Nurbaity, Candra and Fitranti, 2019)

Pengaturan pola makan dengan menghindari makanan yang berbau menyengat, berlemak, bersantan dan berminyak diperlukan untuk mengatasi mual muntah.(Rofi'ah, Widatiningsih and Sukini, 2019) Makanan dilakukan secara perlahan dan dikunyah sampai sempurna serta tetap duduk tegak selama 10-20 menit setelah makan guna menghindari terjadinya refluks lambung. Hindari mengkonsumsi air dalam jumlah yang banyak sekaligus serta hindari makanan pedas, gorengan, dan minum kopi.(Mardiyanti and Zuwariyah, 2019)

Minum teh hangat dengan biscuit, mengkonsumsi buah-buahan segar, minum jus, sari kacang hijau, jahe hangat, mengunyah permen ataupun makan sayuran berkuah akan membantu mengurangi rasa mual muntah.(W and Pertiwi, 2012) Kebutuhan cairan pada ibu hamil sebanyak 3 liter per hari berfungsi untuk mempertahankan homeostasis dalam tubuh dan membantu transportasi zat gizi ke sel dan mengeluarkan sisasisa metabolism. Kebutuhan cairan dapat dipenuhi dari semua minuman, terutama air putih, makanan yang mengandung cairan seperti buah-buahan, sup dan lain-lain.(Mulyani et al., 2018)

Vitamin B6 merupakan pilihan utama dalam mengurangi mual muntah selama kehamilan.(Munjiah et al., 2015) Pemberian vitamin B6 (pyridoxine) sering dilakukan untuk mengatasi masalah mual muntah, karena vitamin B6 berperan dalam metabolisme tubuh seperti fungsi normal system saraf, regulasi hormone, perbaikan jaringan tubuh, dan pembentukan sel darah merah, asam amino dan asam nukleat. Defisiensi vitamin B6 akan menyebabkan penurunan kadar serotonin, sehingga saraf panca indera semakin sensitive yang meningkatkan risiko ibu mengalami mual muntah.(Munjiah et al., 2015) Vitamin B6 termasuk dalam golongan vitamin B kompleks yang berperan membantu tubuh membentuk protein dengan mengubah asam amino dan membantu membentuk energi serta hemoglobin dari protein.(Yuniati, 2012)

Peranan vitamin B6 sebagai koenzim yang memungkinkan terjadinya reaktivitas lisin yang dapat mengurangi mual dan muntah yang disebabkan oleh meningkatnya kadar estrogen pada ibu hamil. Vitamin B6 juga diduga berperan dalam sintesis serotonin, dopamine, norepinefrin, dan asam gamma amino butirat dengan mengkatalis proses dekarboksilasi. Defisiensi asam gamma amino butirat dapat menimbulkan mual dan muntah pada kehamilan.(Nurbaity, Candra and Fitranti, 2019)

Defisiensi vitamin B6 jarang terjadi tanpa berhubungan dengan defisiensi vitamin B kompleks. Asupan vitamin B6 dari bahan makanan nabati mempunyai bioavailabilitas berkisar $50-58 \%$ dan pada bahan makanan campuran nabati dan hewani mempunyai bioavailabilitas berkisar 75\%, sehingga jumlah vitamin B6 yang dikonsumsi dari makanan sehari-hari tidak dapat seluruhnya diserap oleh tubuh.(Nurbaity, Candra and Fitranti, 2019)

Salah satu bahan makanan yang mengandung vitamin B6 adalah pisang kapok dengan kandungan vitamin B6 sebanyak 0,5 mg/100 gram. Namun untuk mengatasi rasa mual muntah saat kehamilan, maka dibutuhkan sebanyak 10 mg vitamin B6, sehingga diperlukan konsumsi pisang kapok yang cukup banyak sekitar 3-4 kali dalam sehari.(Ratih, 2018)

Ibu hamil dengan emesis gravidarum sebaiknya menghindari makanan yang dapat menghasilkan gas dalam perut. Pembentukan gas dan melambatnya gerakan lambung selama kehamilan akan menyebabkan perut 
terasa kembung dan dapat mengiritasi lambung.(Indrayani, Burhan and Widiyanti, 2018) Penderita hyperemesis gravidarum sebaiknya menghindari makanan dan minuman yang mengandung alcohol, kopi dan yang mengandung zat tambahan pangan (pengawet, pewarna, dan bahan penyedap).(Instalasi Gizi Perjan RS Dr. Ciptom Mangunkusumo, 2005)

Perubahan pola konsumsi ibu perlu dilakukan untuk mengatasi hyperemesis gravidarum dengan menghindari makanan yang merangsang seperti pedas, berlemak atau suplemen besi, mengkonsumsi makanan dan minuman dalam porsi kecil namun sering, dan memberikan jenis makanan dalam bentuk makanan ringan, kacang-kacangan, produk olahan susu, kacang panjang, dan biscuit kering, minuman eletrolit dan suplemen gizi per oral serta makanan yang mengandung protein, karena protein bersifat eupeptic dan efektif meredakan mual.(Gunawan, Manengkei and Ocviyanti, 2011)

Edukasi gizi

Edukasi gizi dilakukan oleh Ahli Gizi dengan cara membahas bersama penderita terkait pentingnya makanan yang diberikan untuk mengatasi penyakitnya serta bahas kemungkinan penggunaan bahan makanan lain dan cara pemberiannya dengan ibu dan keluarga. Ahli gizi dan/atau profesi lain secara bersama atau sendiri dapat melatih penderita untuk dapat makan sedikit demi sedikit dalam bentuk roti kering, singkong bakar atau rebus, ubi bakar atau rebus, dan buah-buahan untuk menghindari terpicunya rasa mual. Penderita dilatih untuk dapat memperbaiki pola makannya dan menghindari factor-faktor yang mungkin menjadi pencetus timbulnya rasa mual, terutama yang berkaitan dengan makanan dan minuman. Selain itu, penderita juga dilatih untuk menerapkan Perilaku Hidup Bersih dan Sehat (PHBS). Anjurkan penderita untuk banyak beristirahat dan banyak mengkonsumsi cairan.(Wulandari Agustina, 2018)(Rinata and Ardillah, 2015)

Konseling gizi

Konseling gizi dilakukan pada awal intervensi, pertengahan dan akhir dengan tujuan terjalinnya kolaborasi antara konselor dan klien dalam menetapkan pilihan makanan bergizi, aktivitas, dan mengatasi masalah gizi yang ada. Keterlibatan pihak keluarga sebaiknya dilakukan pada pelaksanaan konseling agar dapat mendukung proses penyembuhan, namun hal tersebut harus dilakukan setelah mendapatkan persetujuan dari klien yang bersangkutan. Dalam kegiatan konseling dibahas terkait cara mengurangi mual, makanan dan minuman yang dianjurkan dan tidak dianjurkan, memberikan saran agar ibu memiliki istirahat yang cukup seperti istirahat siang selama 1-2 jam, dan istirahat malam selama 7-8 jam. Konselor diharapkan dapat memberikan penjelasan kepada ibu kemungkinan timbulnya hyperemesis dan perlunya dukungan keluarga dalam bentuk psikologis.

Dalam konseling gizi juga dapat dibahas terkait perubahan pola hidup dengan membiasakan olahraga ringan seperti jalan kaki di pagi hari, tidak menyikat gigi segera setelah makan, karena menggosok gigi segera setelah makan dapat menimbulkan stimulasi refleks gag (gag reflex) atau reflek muntah, dan menghindari penggunaan pakaian yang ketat agar tidak memberikan tekanan yang tidak nyaman pada perut yang dapat menyebabkan naiknya asam lambung ke kerongkongan dan menimbulkan rasa mual.(Rinata and Ardillah, 2015)

Koordinasi asuhan gizi

Pelaksanaan asuhan gizi yang optimal sangat memerlukan keterlibatan dan Kerjasama yang erat antar berbagai profesi terkait yang bergabung dalam tim asuhan gizi meliputi dokter, perawat, ahli gizi/nutrisionis/dietisien, bidan, dan profesi kesehatan lainnya sebagai pendukung, seperti farmasis, rekam medik dan administrasi. Setiap anggota tim asuhan gizi diharapkan memberikan sumbang saran spesifik sesuai keahliannya dan saling mengisi dalam upaya memberikan asuhan gizi yang optimal. Tim asuhan gizi akan berfungsi efektif bila didukung dengan komunikasi yang teratur, baik secara tertulis melalui rekam medik, maupun secara lisan melalui diskusi sewaktu-waktu atau kunjungan keliling bersama secara periodic.(Instalasi Gizi Perjan RS Dr. Ciptom Mangunkusumo, 2005)

\section{Monitoring dan Evaluasi}

Monitoring dan evaluasi gizi bertujuan untuk melihat perkembangan dan pencapaian tujuan dari intervensi gizi yang dilakukan. Monitoring dan evaluasi dapat dilakukan dalam empat kategori, yaitu pengukuran antropometri, data riwayat gizi, data laboratorium, data klinis/fisik.(Masyarakat, 2018) Pada kasus ibu dengan hyperemesis gravidarum, maka bentuk monitoring dan evaluasi yang dapat dilakukan adalah : 
Monitoring dan evaluasi

o Berkurangnya rasa mual dan muntah pada ibu selama intervensi dilakukan

o Meningkatnya berat badan ibu selama intervensi minimal 500 gram dalam satu minggu.

o Terjadinya peningkatan pengetahuan, keyakinan/sikap/ perilaku ibu terkait dengan Perilaku Hidup Bersih dan Sehat (PHBS), dan factor-faktor yang menyebabkan mual dan muntah serta cara mengatasinya.

o Ibu dapat menghabiskan makanan dan minuman yang diberikan.

Dokumentasi

o Dokumentasi asuhan gizi merupakan catatan tentang hasil pengkajian, penetapan diagnose gizi, intervensi gizi, monitoring dan evaluasi gizi yang telah dilaksanakan oleh Ahli Gizi, termasuk kegiatan dalam bentuk kolaborasi dan koordinasi dalam asuhan gizi.

o Dokumentasi gizi dapat menjadi masukan dalam pengkajian berikutnya bila dalam monitoring dan evaluasi gizi dipandang perlu untuk dilakukan perubahan terhadap siklus asuhan gizi yang dilakukan atau pada penderita dengan kasus yang berulang.

\section{KESIMPULAN}

Ibu hamil dengan hyperemesis gravidarum mengalami penurunan berat badan minimal 5\% dari berat badan sebelum hamil yang disebabkan oleh terjadinya perubahan pola makan, karena nafsu makan yang menurun akibat rasa mual muntah. Asuhan gizi pada ibu dengan hyperemesis gravidarum dimulai dengan pengkajian, diagnosa, intervensi, monitoring dan evaluasi yang merupakan siklus yang berlangsung terus menerus hingga tujuan asuhan gizi tercapai. Asuhan gizi yang tepat dengan kolaborasi yang baik dengan tim asuhan gizi dapat meningkatkan status gizi dan derajat kesehatan ibu, sehingga kematian dapat dihindari.

\section{DAFTAR PUSTAKA}

Astuti, N. D. (2016) HUBUNGAN ANTARA DUKUNGAN SOSIAL DENGAN EMESIS GRAVIDARUM PADA IBU HAMIL TRIMESTER I DI PUSKESMAS KEMBARAN I KABUPATEN BANYUMAS. Universitas Muhammadiyah Purwokerto.

Darniati (2017) HUBUNGAN GRAVIDITAS DAN STATUS GIZI DENGAN HIPEREMESIS GRAVIDARUM PADA IBU HAMIL DI PUSKESMAS MAWASANGKA TENGAH KECAMATAN MAWASANGKA TENGAH KABUPATEN BUTON TENGAH PROPINSI SULAWESI TENGGARA TAHUN 2015 HINGGA 2016. Kendari.

Ebrahimi, N. et al. (2009) 'Nausea and Vomiting of Pregnancy: Using the 24-hour Pregnancy-Unique Quantification of Emesis (PUQE-24) Scale', Journal of Obstetrics and Gynaecology Canada. doi: 10.1016/S1701-2163(16)34298-0.

Faridah, B. (2020) 'Pengaruh minuman jahe terhadap penurunan frekuensi emesis gravidarum pada ibu hamil trimester 1 di wilayah puskesmas lubuk buaya padang', Jurnal Ilmiah Kesehatan Ar-Rum Salatiga.

Gunawan, K., Manengkei, P. S. K. and Ocviyanti, D. (2011) 'Diagnosis dan Tata Laksana Hiperemesis Gravidarum', J Indon Med Assoc.

Histeria Friska Armynia Subratha, D. A. A. K. (2018) EFEKTIFITAS MINUMAN JAHE DALAM MENGURANGI EMESIS GRAVIDARUM PADA IBU HAMIL TRIMESTER I. Tabanan.

Indrayani, I. M., Burhan, R. and Widiyanti, D. (2018) 'EFEKTIFITAS PEMBERIAN WEDANG JAHE TERHADAP FREKUENSI MUAL DAN MUNTAH PADA IBU HAMIL TRIMESTER I DI KABUPATEN BENGKULU UTARA TAHUN 2017', Jurnal Ilmu dan Teknologi Kesehatan. doi: 10.32668/jitek.v5i2.29.

Indrayani, T. (2018) 'Faktor-Faktor Yang Berhubungan Dengan Kejadian Hiperemesis Gravidarum Di Rsud Dr. Drajat Prawiranegara Kabupaten Serang Tahun 2017’, Jurnal Akademi Keperawatan Husada Karya Jaya.

Instalasi Gizi Perjan RS Dr. Ciptom Mangunkusumo, A. D. I. (2005) Penuntun Diet. 2nd edn. Edited by S. Almatsier. Jakarta: PT Gramedia Pustaka Utama. 
Kementerian Kesehatan Republik Indonesia (2019) PERATURAN MENTERI KESEHATAN REPUBLIK INDONESIA NOMOR 28 TAHUN 2019 TENTANG ANGKA KECUKUPAN GIZI YANG DIANJURKAN UNTUK MASYARAKAT INDONESIA. Jakarta: Kementerian Kesehatan Republik Indonesia.

Lindberg, R. et al. (2020) 'Polyunsaturated fatty acids and their metabolites in hyperemesis gravidarum', Nutrients. doi: 10.3390/nu12113384.

Mardiyanti, I. and Zuwariyah, N. (2019) 'THE EFFECTIVENESS OF JSJ (JIN SHIN JYUTSU) IN ADDRESSING EMESIS OF GRAVIDARUM IN PREGNANT WOMEN AT PMB IKA MARDIYANTI SIDOARJO', Nurse and Health: Jurnal Keperawatan. doi: 10.36720/nhjk.v8i1.57.

Masyarakat, D. G. (2018) Pedoman Proses Asuhan Gizi Puskesmas. Jakarta: Kementerian Kesehatan Republik Indonesia.

Maulina, Megamaulia, L. and Widia, L. (2016) 'Hubungan antara status ibu hamil dengan hyperemesis gravidarum di RSIA Paradise Kabupaten Tanah Bumbu’, Jurnal Darul Azhar.

Merlin Karinda, D. (2018) 'Analisis Faktor-faktor yang Mempengaruhi Stress Primigravida Menghadapi Emesis Gravidarum', Jurkessia.

Muhammad Miftahussurur, Heasty Oktaricha, T. S. (2020) 'Clinical Outcome Controversy in Helicobacter pylori Infection', The Indonesian Journal of Gastroenterology, Hepatology and Digestive Endoscopy, 21(2). Available at: http://ina-jghe.com/index.php/jghe/article/view/744/612.

Mulyani, E. Y. et al. (2018) 'Analisis Status Hidrasi dan Asupan Zat Gizi Serta Air pada Ibu Hamil', Media Kesehatan Masyarakat Indonesia. doi: 10.30597/mkmi.v14i3.4343.

Munjiah, I. et al. (2015) 'Perbedaan Pengaruh Akupunktur dan Vitamin B6 terhadap Penurunan Intensitas Mual Muntah pada Emesis Gravidarum Berat', Jurnal Pendidikan dan Pelayanan Kebidanan Indonesia.

Nurazizah, R. (2018) 'PENGETAHUAN IBU HAMIL TRIMESTER I TENTANG EMESIS GRAVIDARUM DI WILAYAH KERJA PUSKESMAS NGASEM KECAMATAN GAMPENGREJO KABUPATEN KEDIRI', Jurnal Kesehatan, 2(1).

Nurbaity, A. D., Candra, A. and Fitranti, D. Y. (2019) 'FAKTOR RISIKO HIPEREMESIS GRAVIDARUM PADA IBU HAMIL DI SEMARANG', Journal of Nutrition College. doi: 10.14710/jnc.v8i3.25801.

Oktavia, N. Sari., Susanti, Dewi., and Anggalia, R. (2018) 'The Effect of Lemon Tea Aromatheraphy on Emesis Gravidarum Reduction in Primigravida Trimester I', Jurnal Kesehatan Ibu dan Anak.

Pratiwi, I. G. (2018) 'PAJANAN INFEKSI HELICOBACTER PYLORI DENGAN HYPEREMESIS GRAVIDARUM', MIKIA: Mimbar Ilmiah Kesehatan Ibu dan Anak (Maternal and Neonatal Health Journal). doi: 10.36696/mikia.v2i1.31.

Qudsi, A. and Jatmiko, H. (2016) 'PREVALENSI KEJADIAN PONV PADA PEMBERIAN MORFIN SEBAGAI ANALGETIK PASCA OPERASI PENDERITA TUMOR PAYUDARA DENGAN ANESTESI UMUM DI RSUP DR. KARIADI SEMARANG', DIPONEGORO MEDICAL JOURNAL (JURNAL KEDOKTERAN DIPONEGORO)

Ratih, R. H. (2018) 'The Vitamin B6 Content of Kepok Banana: an Alternative to Overcome Nausea for Pregnant Women', Jurnal Kesehatan Komunitas. doi: 10.25311/keskom.vol3.iss5.166.

Rinata, E. and Ardillah, F. R. (2015) 'Penanganan Emesis Gravidarum pada Ibu Hamil di BPM Nunik Kustantinna Tulangan-Sidoarjo’, Cultura escrita y oralidad. 
Rofi'ah, S., Widatiningsih, S. and Sukini, T. (2019) 'Efektivitas Aromaterapi Lemon untuk Mengatasi Emesis Gravidarum', JURNAL KEBIDANAN. doi: 10.31983/jkb.v9i1.3814.

Subriani, S. (2018) 'Hubungan Mola hidatidosa dan Gemelli Terhadap Hiperemesis Gravidarum di RSUD Haji Makassar Tahun 2018', JURNAL KESEHATAN DELIMA PELAMONIA. doi: 10.37337/jkdp.v2i1.53.

Syamsuddin, S., Lestari, H. and Fachlevy, A. F. (2018) 'Hubungan Antara Gastritis, Stres, dan Dukungan Suami Pasien dengan Sindrom Hiperemesis Gravidarum di Wilayah Kerja Puskesmas Poasia Kota Kendari’, Jurnal Penelitian dan Pengembangan Pelayanan Kesehatan. doi: 10.22435/jpppk.v2i2.136.

W, V. E. and Pertiwi, H. W. (2012) 'Hubungan Paritas Ibu Hamil Trimester I Dengan Kejadian Emesis Gravidarum Di Puskesmas Teras', Jurnal Kebidanan.

Wulandari Agustina, T. S. (2018) 'PENANGANAN EMESIS GRAVIDARUM PADA IBU HAMIL DI BPM NUNIK KUSTANTINNA TULANGAN - SIDOARJO’, IJMS - Indonesian Journal On Medical Science, 5(2), pp. 149-155.

Yuliana (2019) 'Pengaruh Essensial Lemon Terhadap Emesis Gravidarum pada pada Ibu Trimester I di Kecamatan Natar Kabupaten Lampung Selatan', Wellness and Healthy Magazine.

Yuniati, H. dan A. (2012) 'Kandungan Vitamin B6, B9, B12 Dan E Beberapa Jenis Daging, Telur, Ikan Dan Udang Laut Di Bogor Dan Sekitarnya’, Ejournal.Litbang.Depkes.Go.Id.

Zakiyah, Emyk Windartik, Heri Tri Wibowo, A. (2015) 'EFEKTIFITAS MINUMAN JAHE DALAM MENGURANGI EMESIS GRAVIDARUM PADA IBU HAMIL TRIMESTER I', Adi Husada Nursing Journal. doi: 10.37036/ahnj.v1i2.11. 